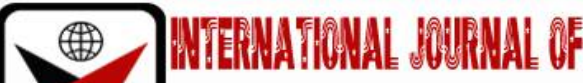

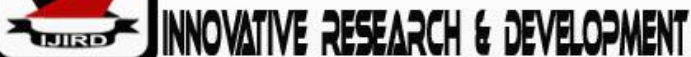

ISSN 2278-0211 (Online)

\section{Assessment of Students' Housing in the University of Uyo, Nigeria}

\author{
Nissi, Chicheta Francis \\ Lecturer, Department of Estate Management, University of Uyo, Nigeria \\ Effiong, Cyril Joseph \\ Lecturer, Department of Urban and Regional Planning, University of Uyo, Nigeria \\ David, Idorenyin Etukudo \\ Student, Department of Estate Management, University of Uyo, Nigeria
}

\begin{abstract}
:
Housing is a complex process that transverses a vast array of components, institution, socioeconomic and historic dimension. In the academic environment, housing has proven to be of immense need to accommodate many students. However, the condition of Students housing in most Nigerian Universities has generated a lot of challenges which sometimes are beyond the University management. For the purpose of collecting data, a population size of 2,700 students were identified through the Student Affairs Division, University of Uyo as total number of students living in hostels. However, the study adopted cross sectional survey design using structured questionnaire administered to three hundred and eighty seven (387) students living in different hostels in Town and Annex campuses of the University using random sampling technique. Data were analyzed using descriptive and Relative Important Index to examine the level of students' satisfaction of hostel facilities on eight indicators of physical, social and management factors. The study concluded that there is Moderate level of students' satisfaction with housing in the University which shows significant level at 49\%, 54\% and 55\% in physical, social and management factors respectively. The study recommends that the university management should partner with private organization or NGO's to build more hostels for both male and female students. They should also adopt appropriate option like "Build, Recover and Return" which will allow private investors to develop hostels, manage them for a number of years (say 30years) and then return it to the University.
\end{abstract}

Keywords: Student, housing, satisfaction, University of Uyo

\section{Introduction}

The desire to live in decent housing has proven to be one of the necessities of man after food. This is the reason Omole, (2001) posited that housing is a unit of environment which has large influence on the health, efficiency and social welfare of the community. In most developed climes, government take considerable action to provide housing to all irrespective of sex, class and profession, they develop housing programmes that is affordable and accessible.

Housing is a complex process that transverses a vast array of components, institution, socioeconomic and historic dimension (Olatobara, 2012). In the academic environment, housing has proven to be of immense need to accommodate many students who are in dire need of campus accommodation. According to Price et al (2003) and Ajayi et al (2005), students housing is one of the essentials parents tend to consider when enrolling their children in tertiary education. This is why most universities in the world developed considerable effort at providing decent housing for students irrespective of sex, class and race. The houses are built such that they can accommodate many students with requisite facilities that will enhance academic performance (Abramson, 2009)

The condition of Students' housing in most Universities across the globe has always generated a lot of challenges which sometimes are beyond the University management. The situation is most worrisome in developing countries like Nigeria, where the number of students in need of hostel accommodation exceed the available facilities. Furthermore, the population of students admitted exerts a lot of pressure on the available facilities thereby rendering some facilities obsolete while others are gradually decaying in usage.

Studies have shown that many tertiary institutions in developing countries are faced with inadequate students' housing due to high rate of students' enrollment. The most worrisome aspect is that there is low level of satisfaction in the available housing as there is continuous exertion of pressure on available facilities (Olatubara, 2001). As observed by Ubong (2007) that student housing is one of the fulcrums of a good university system; and must be provided to satisfy the users need. However, most hostels in Nigerian Universities have witnessed poor sanitary conditions which tend to result in students ill health. This is why Akinmoladun and Oluwoye, (2007); Ibem et al, (2011) said that housing is one of challenges that government has not shown appreciable impact at resolving. Furthermore, the current demand for housing in tertiary institutions is beyond the capacity of university management. 
In the University of Uyo, the condition of hostels has deteriorated due to the pressure exerted on these facilities by the growing population of students. More so, most rooms in the hall of residence are overcrowded as a result of squatters who squat with friends, most of which cannot afford to pay rent for apartment outside the school environment. The problem of unsanitary environment has further resulted in outbreak of disease which affect occupants of the hostel thereby having rippling effect on the entire students of the University. Also, the condition of building is so poor such that some roofs are leaking, the ceiling carved in, and cracking walls.

Satisfaction being a process of evaluation between what was received and what was expected is the most widely adopted description of user satisfaction in the current literature (Parker and Mathews 2001). Satisfying users of any facility (including hostel facility) should be one of the main objectives of providing such facility in the first instance. Singh (2006) believes that user satisfaction has a positive effect on an organization's profitability, educational institution inclusive.

Considering the above assessment, it is pertinent to assess students housing facilities in the University of Uyo, with a view to assessing the level of students' satisfaction on this available accommodation facility and also make provision for more hostel accommodation to meet the need of students housing accommodation in the University.

\section{Literature Review}

Good housing and decent accommodation play a significant role in healthy living and lead to improved productivity. However, it has been established that housing has a profound influence on the health, efficiency, social behavior, satisfaction and general welfare (Agbola,2005). With this, it means that housing exerts influence on overall performance of its residents. Conceptual housing according to Addalia (2000) refers to the degree of contentment experienced by an individual or family with regard to the current housing situation. It is an index for determining the level of contentment with housing.

Satisfaction in housing means the sentiments of satisfaction and happiness to the housing place which creates these feelings (Abramson, 2010). Housing is often viewed as an entity involving a large number of units displaying aspects such as physical quality, location, standard of services offered by the government and private owners as well as neighborhood characteristics (Curley, 2003). The physical entity of housing ties down a person or family to personal services and relationships. A housing that fulfills one's daily needs provide a high satisfaction rate to occupants.

Finally, housing satisfaction acts as a variable in determining the relationship between the resident's background and his attitude towards mobility. There are factors that are associated with housing satisfaction. These factors can be broadly categorized as physical, social and management factors. Physical factors are those related to the physical characteristics of a dwelling and its surrounding environment. Regarding the physical factors, empirical studies have shown that housing satisfaction is associated with an improvement of security control (Mohit, Ibrahim and Rashid 2010); dwelling design and privacy (Day, 2000); unit size and length of stay (Fang, 2006); property value, housing adequacy and available housing space, adaptability and flexibility of spaces (Berkoz et al., 2009); and satisfaction with the facilities of surrounding environment (Patricia and Yusof, 2013). All of these factors emphasize the importance of the physical attributes of the constructed environment on residents' satisfaction. Liu (1999) study residential satisfaction in housing estates: a Hong Kong perspective on automation in construction and study presented factors (on both physical and social levels) which influence residential satisfaction of a sample of occupants in a chosen residential area in Hong Kong.

\subsection{Hostels and Facilities}

Student housing forms part of the facilities that students take into consideration before making a choice of the school they intend to attend among other considerations (Price et al., 2003) this therefore makes it imperative for schools to give student housing a top priority while enhancing the reputation of the school among other contemporaries. As noted by Douglas et al. (2006) schools around the world are in competition for local and internal students and as such efforts should be made to improve student satisfaction while curbing student dissatisfaction. With the world now a global village, demands by student for suitable housing has increased as housing forms part of students need to perform well in their academic exploits.

The student housing is said to include facilities such as; bedrooms which can serve the dual purpose of study and sleeping, bathrooms, water facilities, toilets, kitchen, laundry, electrical facilities, recreational areas and access to internet services as this further enhance the study-learning experience. Abramson (2009) on his part, states that the student housing can be further made exciting by providing further facilities such as ATM machines, car park, mini markets, bookshops and cafeterias within the precinct of the student housing.

However, student housing in Nigeria has not received the desired attention both from the government and the management of the institutions as Ubong (2007) observed that hostel accommodation has not received adequate attention in Nigeria although it is an important component of pupil personnel management. He portrays that this might be due to the national indifference arising from the people being used to general poor performance of social services. Adewunmi et al. (2011) noted that, inadequate maintenance of the services and infrastructure of hostel accommodation is very common. There have been reported cases of students taking ill in the hostels as a result of poor sanitary conditions. Adequate screening of students allocated to rooms are not carried out which sometimes pose a threat to the life and property of the other fellow students as criminals find it easy to enter the hostel. Several researches have been conducted by various researchers into student housing such as Alkandari (2007) in Kuwait in which students' perception of the residence hall was compared with the living environment, the result showed that students were satisfied with the housing facilities. Douglas et al (2006) carried out a study on student satisfaction in the UK, student housing was just a fraction of the factors under consideration as emphasis was placed more on the teaching and administrative aspect of the school, Petruzzellis et 
al. (2006) on student satisfaction in Italian universities looked at the entire school system such as lecture halls, laboratories, library, scholarships and so on, it was not concentrated on the student housing. Butt and Rehaman (2010) of student's satisfaction in Pakistan also took a holistic look at the school with student housing forming a fraction of factors under consideration.

\subsection{Level of Satisfaction}

Satisfaction is an act of fulfilling a need, desire, or appetite, or the feeling gained from such fulfillment. Satisfaction towards the housing environment reflects residents' reaction towards their living environment. In general, housing has been accepted as a main component towards a quality life. The concept of housing satisfaction is multi-layered. Elsinga and Hoeksta (2005) and Hassanain (2008) display similar views on the concept of housing satisfaction based on their observation on past studies. In their opinion, the concept of housing satisfaction has been used for three major objectives. It is the key to predict an individual's perception on the overall quality of life. It is also an indicator of individual mobility which later changes the demand on housing and influences surrounding area change. Thirdly, it is used as an ad hoc measurement of private sector development success as an evaluation tool to measure resident's acceptance of prevailing shortcomings for existing surrounding area development.

Housing satisfaction is also related to the concept of live ability (Ogbazi, 2015). This is because housing satisfaction is a function of the dwellers' overall health, efficiency and social behaviour. The immediate social environment of a dwelling is also a major factor of live ability and satisfaction (Olatubara, 2012). Other determinants of housing satisfaction in Nigeria as reported by Effiong and Nissi, (2018) in urban households include facilities such as types of energy and light, water supply, toilet, other waste disposal facilities.

\section{Methodology}

This study adopts a cross-sectional survey approach. The population consists of students living in hostel in Town and Annex Campuses of University of Uyo. 387 copies of questionnaire were administered to students residing in M2, hall 1, hall $2 \mathrm{~A}$, hall $2 \mathrm{~B}$, hall $3 \mathrm{~A}$, hall $3 \mathrm{~B}$ hall 4 , hall 5 , hall $6 \mathrm{~A} \& \mathrm{~B}$ using random sampling technique. The study identified eight indicators each from literature covering physical, social and management factors. The choice of these factors is that housing is viewed as an entity involving a large number of units displaying aspects such as physical quality, location and standard of services (Curley, 2003).

Data on the level of students' satisfaction were measured on five-point Likert scale namely Strongly Agree =1, Disagree =2, Partially Agree =3, Agree =4 and Strongly Agree =5. The Relative Important Index Method was used in the study to determine the level of students' satisfaction in line with the formula used by Ugwu and Haupt, (2007) and Enshassi, Mohamed and Abushaban (2009) as shown in equation 1

$\mathrm{RII}=\sum \mathrm{W} / \mathrm{AxN}$

Where $\mathrm{W}$ is the weight given to each variable by the respondents and ranges from 1-5; A- the highest weight =5; $\mathrm{N}-$ the total number of respondents. The RII were then classified as 0-0.359 very low significance (VLS); 0.36- 0.529 low significance (LS); 0.53-0.679 moderate significance (MS); 0.68-0.839 high significance (HS) and $0.84-1.0$ very high significance (VHS).

\section{Presentation and Discussion of Findings}

\subsection{Characteristics of Respondents Used for the Study}

The general characteristics of students living in the hostel are seen in the proportion of Male (11.36\%) and female $(88.64 \%)$. The study reveals that majority of respondents living in University of Uyo hostel are mostly females. This is because there are more female hostels than male in the University of Uyo.

The Age characteristics are represented as 16-20years, (30.75\%,) 21-25years (41.60\%), 26-30years (22.48\%), 31-35years (5.17\%). This shows that age bracket of 21-25years are within the school age and is ideal for them to access hostel facilities in order to improve academic performance. However, more respondents were in year five with a percentage of $(23.53 \%)$ and year 1 students with $(23.00 \%)$. This is in line with the university policy that allocates more bed space for year1 and year 5 students.

Also, students responded to the number of sessions they have lived in hostel. (32.56\%) have only stayed in the hostel for between 1 to 2 sessions. $25.32 \%$ have stayed 3 to 4 sessions, $42.12 \%$ have stayed 5 to 6 sessions. Most respondents have lived more than 4-5 sessions in the hostel.

Most students choose to live in the hostel due to the reduced cost of hostel accommodation, availability of constant light, and proximity (i.e. nearness to school environment) as expressed in percentage 32.29\%, 31.78\% and $22.73 \%$ respectively. Majority of students choose to live in hostel because of the constant lighting system, as availability of electricity aids academic performance/reading. 30 (7.75\%) respondent choose to live in the hostel so they could meets and participate in student politics, $10(2.50 \%)$ respondent said choose to live in the hostel in order to participate in games. It can be deduced from the study, that majority of students choose to live in hostel because of the low cost and constant lighting system in the university environment. 


\begin{tabular}{|c|c|c|c|}
\hline $\begin{array}{c}\text { Characteristics of } \\
\text { Respondents }\end{array}$ & Sub Characteristics & Frequency & Percentage \\
\hline \multirow[t]{2}{*}{ Gender of Respondent } & $\begin{array}{c}\text { Male } \\
\text { Female }\end{array}$ & $\begin{array}{c}44 \\
343\end{array}$ & $\begin{array}{l}11.36 \\
88.64\end{array}$ \\
\hline & Total & 387 & 100 \\
\hline \multirow[t]{2}{*}{ Age of Respondents } & $\begin{array}{l}\text { 16-20years } \\
21-25 \text { years } \\
26-30 \text { years } \\
31-35 \text { years }\end{array}$ & $\begin{array}{c}119 \\
161 \\
87 \\
20 \\
\end{array}$ & $\begin{array}{c}30.75 \\
41.60 \\
22.48 \\
5.17 \\
\end{array}$ \\
\hline & Total & 387 & 100 \\
\hline \multirow[t]{2}{*}{ Level of Respondents } & $\begin{array}{l}\text { Year } 1 \\
\text { Year } 2 \\
\text { Year } 3 \\
\text { Year } 4 \\
\text { Year } 5 \\
\end{array}$ & $\begin{array}{l}89 \\
58 \\
85 \\
63 \\
92 \\
\end{array}$ & $\begin{array}{l}23.00 \\
14.99 \\
21.96 \\
16.28 \\
23.77 \\
\end{array}$ \\
\hline & Total & 387 & 100 \\
\hline \multirow[t]{2}{*}{$\begin{array}{l}\text { Number of session stayed in } \\
\text { hostel }\end{array}$} & $\begin{array}{l}\text { 1-2 session } \\
3-4 \text { session } \\
5-6 \text { session }\end{array}$ & $\begin{array}{c}126 \\
98 \\
163\end{array}$ & $\begin{array}{l}32.56 \\
25.32 \\
42.12\end{array}$ \\
\hline & Total & 387 & 100 \\
\hline \multirow[t]{2}{*}{$\begin{array}{c}\text { Reason why student live in } \\
\text { hostel }\end{array}$} & $\begin{array}{c}\text { Proximity } \\
\text { Constant light } \\
\text { Reduced cost } \\
\text { Engage in social activities } \\
\text { Others specify }\end{array}$ & $\begin{array}{c}88 \\
123 \\
125 \\
40 \\
11\end{array}$ & $\begin{array}{c}22.73 \\
31.78 \\
32.29 \\
10.34 \\
2.84\end{array}$ \\
\hline & Total & 387 & 100 \\
\hline
\end{tabular}

Table 1: Characteristics of Respondents

Source: Researchers' Field Survey, 2019

\subsection{Condition of Facilities in University of Uyo Hostels}

Results revealed that Electricity was adjudged very good while facilities like water, waste disposal, Bunks, wardrobe were in good condition. Facilities that were moderate are bulbs $0.63 \%$, fans 0.60 , doors $0.57 \%$ windows $0.56 \%$, socket $0.65 \%$. Facilities that were poor include toilet $0.36 \%$, bathroom $0.39 \%$, water taps $0.37 \%$, while facilities that were in very poor condition are laundry $0.04 \%$, drainage $0.35 \%$, security $0.28 \%$, firefighting equipment $0.32 \%$, ICT/reading room $0.26 \%$.

Furthermore, it can be deduced from the study that many facilities that were in poor condition was as a result of overcrowding in the University hostel which exert pressure on the facilities thus rendering them obsolete. Also some facilities were very poor because they are not in existence while some facilities have undergone many years of usage without replacement.

\begin{tabular}{|c|c|c|c|c|c|c|c|}
\hline \multicolumn{8}{|c|}{$N=387$} \\
\hline Facilities & 5 & 4 & 3 & 2 & 1 & Total & Rll \\
\hline Electricity & 925 & 456 & 201 & 30 & 6 & 1618 & 0.84 \\
\hline Water & 470 & 292 & 591 & 24 & 11 & 1388 & 0.72 \\
\hline Waste & 400 & 696 & 290 & 80 & 13 & 1479 & 0.76 \\
\hline Laundry & 20 & 140 & 168 & 244 & 120 & 729 & 0.04 \\
\hline Toilet & 10 & 20 & 150 & 382 & 137 & 699 & 0.36 \\
\hline Bathroom & 10 & 64 & 282 & 388 & 81 & 762 & 0.39 \\
\hline Drainage & 50 & 72 & 60 & 300 & 189 & 671 & 0.35 \\
\hline Recreational Room & 130 & 160 & 840 & 54 & 14 & 1198 & 0.62 \\
\hline Bunks & 90 & 828 & 402 & 24 & 16 & 1360 & 0.70 \\
\hline Blubs & 85 & 384 & 633 & 90 & 18 & 1210 & 0.63 \\
\hline Fan & 55 & 288 & 480 & 244 & 90 & 1157 & 0.60 \\
\hline Doors & 50 & 312 & 522 & 170 & 40 & 1094 & 0.57 \\
\hline Windows & 50 & 292 & 519 & 180 & 41 & 1082 & 0.56 \\
\hline Socket & 405 & 48 & 621 & 134 & 11 & 1255 & 0.65 \\
\hline Water Taps & 10 & 112 & 90 & 330 & 162 & 714 & 0.37 \\
\hline Security & 5 & 28 & 48 & 194 & 266 & 541 & 0.28 \\
\hline Firefighting equipment & 10 & 12 & 6 & 432 & 164 & 624 & 0.32 \\
\hline Wardrobe & 110 & 688 & 507 & 36 & 6 & 1347 & 0.70 \\
\hline ICT/reading room & 15 & 20 & 21 & 162 & 291 & 509 & 0.26 \\
\hline
\end{tabular}

Table 2: Condition of Facilities

Source: Researchers' Field Survey, 2019

\subsection{Challenges Facing Students in Hostels in the University of Uyo}

From the Table 3 show challenge(s) facing hostels in University of Uyo 125 respondents representing 32.99\% said security is a major challenges facing hostel in University of Uyo. $32.0 \%$ respondents said overcrowding as a challenge 
facing hostel. 2.41\% of respondents said water is a challenge, $29.1 \%$ said poor sanitary facility, 5 respondents representing $1.20 \%$ said poor electrification and $2.3 \%$ of respondents said others specify the challenges. It can be deduced that security and overcrowding are the major challenge facing hostels in University of Uyo. This collaborate the work of Akasike et al., (2019), a publication of punch newspaper, which asserted that overcrowding and poor facilities worsen students' lives in federal Universities hostels. It is even more worrisome that most students contribute to the deteriorate facilities in the hostel. Some students would not bother to fetch water to clean the conciseness because of the stress involved. In addition to this problem the rooms are overcrowded.

\begin{tabular}{|c|c|c|}
\hline Challenges & Frequency & Percentage \\
\hline Security & 125 & 32.99 \\
\hline Overcrowding & 129 & 32.0 \\
\hline Water & 10 & 2.41 \\
\hline Poor sanitary/facility & 118 & 29.1 \\
\hline Poor electrification & 5 & 1.20 \\
\hline Others specify & 10 & 2.3 \\
\hline Total & 387 & 100 \\
\hline
\end{tabular}

Table 3: Challenge(s) Facing Hostels

Source: Researchers' Field Survey, 2019

\subsection{Students' Level of Satisfaction}

The students' level of satisfaction was measured with eight indicators each covering physical factors, social and management factors. The result revealed that RII in Physical indicators yielded Very low level of satisfaction in Improvement of security control. Furthermore, the result yielded low level of significant in factors of Design and Privacy (0.41), Housing space and Ventilation (0.47), satisfaction with facilities, convenience (0.48) and satisfaction with aesthetics (0.49). The result yielded moderate in factors of Unit size and number of persons per room (0.56), adaptability and flexibility (0.56), and satisfaction with the environmental quality (0.60)

The social factors yielded low significant in factors of improve sporting activities, enhance cultural ethnicity and good sanitary condition with RII $0.60,0.50$ and 0.47 respectively. The result yielded moderate significant in factors of foster friendship, improve academic performance, enhance social cohesion, improve welfare of student and promote student politics.

In management factors the result yielded low level of significant in ban on cooking (0.49) and regulate waste disposal (0.49). however, the result yielded moderate level of significant in factors of develop good policy, time for visiting, direct construction of new hostel, partnership with private investors and direct private management of hostel.

\begin{tabular}{|c|c|c|c|c|c|c|c|}
\hline Physical Factors & $\mathbf{5}$ & $\mathbf{4}$ & $\mathbf{3}$ & $\mathbf{2}$ & $\mathbf{1}$ & TOTAL & R11 \\
\hline Improvement of security control & 80 & 196 & 72 & 218 & 189 & 755 & 0.39 \\
\hline Design and privacy & 100 & 100 & 270 & 152 & 176 & 798 & 0.41 \\
\hline Unit size and no. of persons per room & 370 & 104 & 252 & 296 & 55 & 1077 & 0.56 \\
\hline Housing space/ ventilation & 345 & 124 & 102 & 208 & 129 & 908 & 0.47 \\
\hline Adaptability and flexibility & 155 & 374 & 273 & 160 & 91 & 1053 & 0.54 \\
\hline Satisfaction with facilities and convenience & 195 & 108 & 276 & 240 & 109 & 928 & 0.48 \\
\hline Satisfaction with environmental quantity & 430 & 288 & 243 & 100 & 98 & 1159 & 0.60 \\
\hline Satisfaction with aesthetics & 75 & 276 & 276 & 214 & 104 & 945 & 0.49 \\
\hline SOCIAL FACTORS & & & & & & & \\
\hline Foster friendship & 595 & 116 & 312 & 250 & 10 & 1283 & 0.66 \\
\hline Improve academic performance & 265 & 356 & 300 & 260 & 15 & 1196 & 0.62 \\
\hline Enhance social cohesion & 400 & 112 & 420 & 254 & 12 & 1186 & 0.61 \\
\hline Improved sporting activities & 90 & 196 & 165 & 240 & 144 & 835 & 0.43 \\
\hline Enhance cultural and ethnicity & 205 & 68 & 360 & 244 & 87 & 964 & 0.50 \\
\hline Improve welfare and student & 360 & 100 & 252 & 204 & 104 & 1020 & 0.53 \\
\hline Promote students politics & 270 & 256 & 252 & 244 & 55 & 1084 & 0.56 \\
\hline Good sanitary condition & 205 & 52 & 261 & 284 & 104 & 906 & 0.47 \\
\hline MANAGEMENT FACTORS & & & & & & & \\
\hline Ban on the use of tent & 450 & 288 & 426 & 100 & 33 & 1297 & 0.67 \\
\hline Ban on cooking & 105 & 348 & 270 & 60 & 159 & 942 & 0.49 \\
\hline Develop good hostel policy & 470 & 240 & 162 & 148 & 105 & 1125 & 0.58 \\
\hline Time for visiting & 120 & 296 & 291 & 222 & 88 & 1017 & 0.53 \\
\hline Direct construction of new hostel & 250 & 368 & 183 & 160 & 104 & 1065 & 0.55 \\
\hline Partnership with private investor & 500 & 300 & 72 & 38 & 169 & 1079 & 0.56 \\
\hline Regulate waste disposal and management & 415 & 280 & 111 & 94 & 150 & 1050 & 0.54 \\
\hline
\end{tabular}

Table 4: Students' Level of Satisfaction

Source: Researchers' Field Survey, 2019 


\section{Discussion of Findings}

The study has revealed that there are 10 hostels in university of Uyo. 4 hostels are in Annex campus which are M2- male hostel, W1, W4 and W5 which are female hostels. In town campus of the University, there are 6 hostels which are all for female- they include- W2A and B, W3A and B, W6A and B. The study also revealed that M2 has 63 rooms accommodating 330 students. W1 has 35 rooms accommodating 310 students, W2A has 35 rooms accommodating 180 students, W2B has 35rooms accommodating 180 students, W3A has 35 rooms accommodating 180 students, W3B has 35 rooms accommodating 180 students, W4 has 35 rooms accommodating 310 students, W5 has 35 rooms accommodating 310 students, W6A has 35 rooms accommodating 360 students, W6B has 35 rooms accommodating 360 students. However the study has revealed that the number of occupants has doubled in some rooms due to increasing demand by students who were not given hostel accommodation who later resort to squatting with relatives and friends.

The work has revealed that facilities in the hostels are in very poor condition. This is attributed to the over crowdedness witness in some rooms thereby exerting pressure on existing facilities. The study has revealed that some major facilities that would have improved academic performance are lacking in the hostels. These facilities include reading room, laundry, ICT, firefighting security.

The study has revealed that students are moderately satisfied with students housing in University of Uyo considering eight indicators covering physical, social and management factors. However, the result yielded $49 \%$ for physical factors $55 \%$ for social factors and $54 \%$ for management factors. This revealed that there is moderate level of satisfaction which is sequel to the observation made by Parker and Mathews (2001) who said satisfying users of any facility (including hostel facility) should be one of the main objectives of providing such facility in the first instance. Likewise Singh (2006) believing that user satisfaction has a positive effect on student performance and Sivadas (2000) state that it is not enough to merely satisfy users but importantly, ensure users are extremely satisfied.

The research work revealed that challenges faced by students' in hostel ranges from security, overcrowded rooms and poor sanitary facilities which is in line with the work of Jiboye, (2009) they asserted that the major difficulties that students go through are not limited to having spacious room not feeling comfortable, ventilation, and poor sanitary condition of hostels.

\section{Conclusion}

The study was conducted to assess students' housing in University of Uyo. The study assessed hostel facilities and the state of facilities. From the study, facilities available were identified, the state of the facilities known and the satisfaction level ascertained. However the result revealed that increase in population has exerted a lot of pressure on the existing facilities. The study has also examined the level of student satisfaction on eight indicators covering physical, social and management factors. The student faces challenges ranges from lack of water provision, poor sanitary condition and overcrowding.

The University management should consider ways of improving hostel facilities in line with the international best practice in such a way it will boost academic performance of students. Also, hostel management strategy should improve the security challenges currently bedeviling the University system.

\section{Recommendation}

The university management should partner with private organization or NGO's to build more hostels for both male and female students. They should adopt appropriate option like "Build, Recover and Return". This option will allow private investors to come in, develop hostels, manage for a number of years (say 30years) and then return it to the University. This will check for proper management of hostel facilities including squatters which usually characterize hostels in most Nigerian Universities.

The university should introduce "caution fee" and bill it into hostel accommodation fee. The caution fee will be used to replace any spoilt facility in the hostel. However, the caution fee can be refunded to students who did not destroy any property during their stay in hostel. This will checkmate students' carefree attitude towards hostel facilities. Also, the University Management should do routine check on weekly bases, and make adequate replacement of facilities where necessary and funding should be made available for this purpose.

The university management should replace and provide current facilities. Most importantly, the university management should ensure that facilities that aid students' academic performance such as well-equipped reading room and internet connectivity are prioritized. This will help to improve the satisfaction level among students with hostel facilities.

The university management should recruit private security to manage the hostels as this will help to safeguard the hostel and to ensure that students are checked before entry into the hostel. This will help reduce the problem of insecurity in the hostel. If the university partner with private individuals they will know how to manage the existing hostels and facilities provided.

The university management should provide enough hostels to accommodate students as their desire to live in the hostel is due to constant electricity supply, reduced accommodation cost and proximity. Therefore, the University management should provide more hostels to this effect. 


\section{References}

i. Abramson, P. (2010), "Downsizing residence halls: space and costs", living on campus, 2009 college housing report, vol. 12 no.5, pp.20-27

ii. Adewunmi, Y. Omirin, M. Famuyiwa, F. and Frinloye, 0. 92011). "Post-occupancy evaluation of Postgraduate hostel facilities”. Journal of Facilities Management, Vol. 29 No. 3 pp. 149-168.

iii. Agbola, S. B. (2005) The Housing Debacle' Inaugural Lecture Delivered at the University of Ibadan Thursday, August 4th 2005

iv. Akasike, C., Olaleye A., Femi A., Dayo O., Tare Y., Ada W., Rapael E., Adeniyi O., Bola B., Godwin, I. and Ademola B. (2019) Overcrowding, poor facilities worsen students' woes in FG varsities' hostels. A Punch Newspaper publication of July 29,2019.

v. Alkandari, N. (2007) Students perception of the residence hall living environment at Kuwait University. College student Journal, 41(2) p. 327-335

vi. $\quad$ Berkoz, L., Turk S.S. E. and Kellekci, O. M. L. (2009) "Environmental quality and user satisfaction in mass housing areas: the case of Istanbul", European Planning Studies, Vol. 17, pp. 161-74.

vii. Butt, B.Z and Rehman, K. (2010) A study examining the students Satisfaction in higher education, Procedia- Social and Behavioral Sciences, Vol.2 No. 2, Pp. 5446-50.

viii. Curely, P. (2003). "Residence halls: Making campus a home”, American School and University, $\quad$ Vol. 75 No. 12 , pp. 245- 256.

ix. Day, L.L. (2000), "Choosing a house: the relationship between dwelling type, perception of privacy and residential satisfaction”, journal of Planning Education and Research, vol.19, pp. 265-275

X. Douglas, J. Douglas, A. and Barnes, B. (2006) Measuring Student Satisfaction at a Uk University. Emerald Quality Assurance in Education. Vol. 14 No.3, PP251-267.

xi. Effiong, C. J. and Nissi, C. F. (2018) Determinants of House Ownership Among University of Uyo Staff: Emerging Lessons. Journal of Environment and Earth Science. IISTE Publication. Vol.8. No. 7, Pp 1-8

xii. Elsinga, M. and Hoektra, J. (2005), "Home ownership and Housing Satisfaction", Journal of Housing and the Built Environment, vol. 20, pp. 401-424.

xiii. Fang, Y. (2006), "Residential satisfaction, moving intention and moving behaviours: a study of Redeveloped Neighborhoods in inner-city Beijing", housing studies, vol.21, pp. 671-694.

xiv. Hassanain, M.A (2008), "on the performance evaluation of sustainable student housing Facilities", Journal of Facilities Management, vol.6 no.3, pp.212-225

xv. Jiboye, A.D (2009). The Challenges of Sustainable Housing and Urban Development in Nigeria. Journal of Environmental Research and Policies, 4(3), 23-27.

xvi. Khozaei, F., Hassan, A.S and Khozaei, Z. (2007). Undergraduate students' satisfaction with hostel and sense of attachment to place: a Case Study of University Sains Malaysia

xvii. Lin, A.M.N (1999) Residential Satisfaction in Housing Estate: A Hong Kong perspective, Automation in construction vol.8, pp 511-524

xviii. Ogbazi, J. U (2015): Management of Sustainable Cities in the $21^{\text {st }}$ Century: Coordination of Agencies in Urban Service Delivery. A paper presented at the 28 ${ }^{\text {th }}$ TOPREC Induction Ceremony, July, 30th 2015.

xix. Olatubara, C. 0. (2012) Housing in Nigeria: The Socio-Cultural Milieu. An Inaugural Lecture at the University of Ibadan on Thursday, 20th September 2012.

xx. Omole, F. K. (2001) Basic Issues in Housing Development. A Femo Bless Publications, London.

xxi. Parker, C. and Mathews, B. P. (2001) Customer Satisfaction: Contrasting Academic and Consumers Interpretations, Marketing Intelligence and Planning, 19 (1): 38-46.

xxii. Patricia T. S. and Yusuf N.A (2013), "Students satisfaction with hostel features in Nigeria polytechnic: a case study of Kaduna polytechnic" journal of features management vol. 11 no. 4, pp 306-322

xxiii. Petruzzellis, L. D’Uggento, A.M. and Romanazzi, S. (2006). "Student satisfaction Services in Italian Universities" Managing Service Quality, Vol. 16 No.4 pp. 349-364.

xxiv. Price, I., Mazdorf, F. Smith, L. and Agahi, H. (2003), "The Impact of Facilities on Students Choice of University", Journal of Facilities. Vol. 21 no.10, pp. 212-222

xxv. Singh, H. (2006) The Importance of Customer Satisfaction in Relation to Customer loyalty and Retention, pp.1-7

xxvi. Sivadass, E. and Baker-Parwith, J.L (2000), An Examination of the Relationship between Service Quality, Customer Satisfaction and Store Loyalty, International Journal of Retail and Distribution Management, 28(2), pp. 73-82

xxvii. Ubong, B. (2007), Hostel Accommodation in Tertiary Educational Institutions in Nigeria. Available at www.basseyubong.com/Hostel\%20Accommodation.

xxviii. Ugwu, O. and Haupt, T. C. (2007) Key Performance and Indicators and Assessment methods For Infrastructure sustainability. A South African Construction Industry Perspective, Building and Environment 42:665-680. 